\title{
Neurovascular Structures at Risk During Anterolateral and Medial Arthroscopic Approaches of the Hip
}

\author{
Estructuras Neurovasculares en Riesgo Durante Abordajes \\ Artroscopicos Anterolaterales y Mediales de la Cadera
}

\begin{abstract}
Omar Méndez-Aguirre*; Rodolfo Morales-Avalos*; Gustavo A. Compeán-Martínez*; Abraham G. Espinosa-Uribe*; Félix Vílchez-Cavazos"; María del Carmen Theriot-Giron"**; Alejandro Quiroga-Garza*; Oscar de la Garza-Castro*; Katia Guzmán Avilán*; Santos Guzmán-López* \& Rodrigo E. Elizondo-Omaña*
\end{abstract}

MÉNDEZ-AGUIRRE, O.; MORALES-AVALOS, R.; COMPEÁN-MARTÍNEZ, G. A.; ESPINOSA-URIBE, A. G.; VÍLCHEZCAVAZOS, F.; THERIOT-GIRON, M. C.; QUIROGA-GARZA, A.; DE LA GARZA-CASTRO, O.; GUZMÁN-AVILÁN, K.; GUZMÁN-LÓPEZ, S. \& ELIZONDO-OMAÑA, R. E. Neurovascular structures at risk during anterolateral and medial arthroscopic approaches of the hip. Int. J. Morphol., 34(2):752-758, 2016.

SUMMARY: To describe the safety areas for placement of 5 anterolateral portals (anterior, anterior lateral, posterior lateral, proximal anterior medial and distal anterior medial portals) and 3 recently described medial portals (anterior medial, posterior medial and distal posterior medial portals) to provide topographical description of the safety of each. A descriptive, observational and crosssectional study in which femoral triangle dissection was performed in 12 hips. 5 lateral portals and the 3 medial portals were placed. Clinically relevant neurovascular structures associated with each portal, were identified measured and documented. The lateral portal with the highest risk of injury to a nearby neurovascular structure was the anterior portal, the most adjacent to the femoral cutaneous nerve, $1.42 \mathrm{~cm}( \pm 0.85)$ lateral to the portal. In the medial portals, the anterior medial portal has the narrowest margin in relation to the femoral artery, $2.14 \mathrm{~cm}( \pm 0.35)$ lateral to the portal and medial to the obturator nerve by $0.87 \mathrm{~cm}( \pm 0.62)$. The lateral portals have a higher safety margin; the portal with the most proximity to a neurovascular structure is the anterior portal, associated laterally with the femoral cutaneous nerve, presenting a higher risk of injury. Medial portals have a higher risk of injuring the femoral neurovascular bundle as well as the obturator nerve.

KEY WORDS: Anatomy; Arthroscopy; Hip; Portal.

\section{INTRODUCTION}

Hip arthroscopy is a minimally invasive surgical technique, commonly used to treat various pathologies of the hip joint (Byrd, 1994; Thorey et al., 2013). Its advantages are: greater conservation of joint stability, reduced risk of avascular necrosis of the femoral head, and postoperative infections. It allows for a faster rehabilitation and superior clinical outcomes (Bozic et al., 2013; Gupta et al., 2014; Sampson, 2001).

Among the hip pathologies that can be treated by arthroscopy are the femoroacetabular impingement, intraarticular loose bodies, traumatic chondral lesion, acetabular labral tear, gluteus medius insertion tendinous tear, deep gluteal syndrome piriformis syndrome and snapping hip syndrome (Byrd et al., 1995; Byrd; Matsuda, 2009; Nossa et al., 2007). To obtain adequate access and outcome, precise positioning of the arthroscopic portals in safe areas is needed to avoid neurovascular injury of neighboring structures (Sampson).

The most important and frequent complications of hip arthroscopy described in the literature are: neuropraxia, instability, heterotopic ossification, femoral neck fracture, among others. Furthermore, there are other placement site related complications, for example: nerve, vascular and condrolabral injury (Gupta et al.).

\footnotetext{
* Department of Human Anatomy, Faculty of Medicine, Universidad Autónoma de Nuevo León, Nuevo León, México.

** Orthopedics and Traumatology Service, University Hospital “Dr. José Eleuterio González”, Universidad Autónoma de Nuevo León, Nuevo León, México.

**** Department of Human Anatomy, School of Dentistry, Universidad Autónoma de Nuevo León, Nuevo León, México.
} 
MÉNDEZ-AGUIRRE, O.; MORALES-AVALOS, R.; COMPEÁN-MARTÍNEZ, G. A.; ESPINOSA-URIBE, A. G.; VÍLCHEZ-CAVAZOS, F.; THERIOT-GIRON, M. C.; QUIROGAGARZA, A.; DE LA GARZA-CASTRO, O.; GUZMÁN-AVILÁN, K.; GUZMÁN-LÓPEZ, S. \& ELIZONDO-OMAÑA, R. E. Neurovascular structures at risk during anterolateral and medial arthroscopic approaches of the hip. Int. J. Morphol., 34(2):752-758, 2016.

The recent and rapid development of arthroscopic hip technique, and the emerging therapeutic needs for many diseases of the hip joint and related structures, have resulted in the description of, up to 18 different arthroscopic portal sites in various articles; however, some of them do not use the internationally standardized terminology, nor do they specify the indications for the use of each (Byrd et al.; Robertson \& Kelly, 2008). The aim of this study was to evaluate the safety areas of arthroscopic portals in anterolateral positions (5) as well as medial positions (3), anddescribe the neurovascular structures at risk of being injured by each.

\section{MATERIAL AND METHOD}

This was an anatomical, observational, transverse and descriptive study. The sample consisted of twelve hips from six previously embalmed male cadavers from the Human Anatomy Department at the, Faculty of Medicine and Dentistry at the Universidad Autónoma de Nuevo León (U.A.N.L.). The cadavers have the following characteristics: age range between 27 and 62 years (mean 43.83 \pm 13.65 ), weighing between 43 and $80 \mathrm{~kg}$ (mean $60.16 \pm 12.62 \mathrm{~kg}$ ), height between 1.55 and $1.76 \mathrm{~m}$ (mean of $1.67 \pm 0.07 \mathrm{~m}$ ) and BMI between 17.91 and $27.11 \mathrm{~kg} / \mathrm{m}^{2}$ (mean $21.59 \pm 3.10 \mathrm{~kg} /$ $\mathrm{m} 2$ ). All samples included in the study had no history of previous hip disease or surgery.

An experienced surgeon, specialist in arthroscopic hip surgery (FVC) placed each of the medial and anterolateral arthroscopic portals. Standard surgical protocol for positioning the body, traction of the lower limb, as well as the location and placement of the portals was followed (Nossa et al.; Robertson \& Kelly; Philippon, 2006).

The anterolateral portals studied were: Anterior Portal (AP), Anterior Lateral Portal (ALP), Posterior Lateral Portal (PLP), Proximal Anterior Medial Portal (PAMP) and Distal Anterior Medial Portal (DAMP). anterolateral portals were placed on the cadaver in a supine position with a thigh abduction of $10^{\circ}$ and a flexion of $20^{\circ}$. A $30 \mathrm{~kg}$ traction was applied to the lower extremity to achieve an intracapsular distension of approximately one centimeter. The medial portals studied were: Anterior Medial Portal (AMP), Posterior Medial Portal (PMP) and Distal Posterior Medial Portal (DPMP). For the medial portals, the cadaver was placed in a supine position with a thigh abduction of $70^{\circ}$ and a flexion of $70^{\circ}$, applying a full external rotation (Polesello et al., 2014). Fluroscopy (fluoroscopy C-arm KMC 950 brand-eat) was used to confirm and evaluate the effectiveness of intracapsular distention and placement of each portal (Fig. 1).

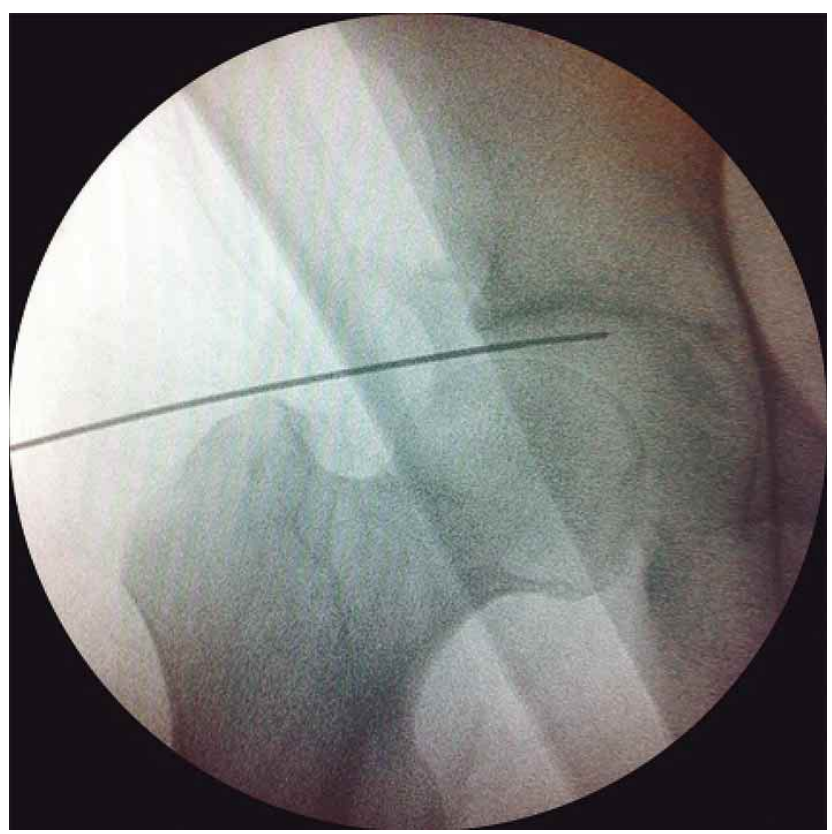

Fig. 1. Anteroposterior image of the hip by fluoroscopy to confirm the placement of Steinmann nails in the correct intraarticular location.

The location for placement of the anterolateral portals was delimited with a triangle formed with a line drawn using a surgical marker between the anterior superior iliac spine (ASIS) and the upper margin of the greater trochanter of the femur, a second longitudinal line drawn from the ASIS to the midpoint of the upper margin of the patella, and a third transverse line perpendicular to the first one extending from the upper margin of the pubic symphysis to the upper margin of the greater trochanter (Philippon et al., 2007; Robertson \& Kelly). The location of the anterolateral portals was documented in quadrants using a coordinate system to make placement more objective, and for a better understanding of their location, relative to each of the neurovascular structures. The horizontal axis ( $\mathrm{X}$ axis) was represented by a transverse imaginary line running from the upper margin of the pubic symphysis to the upper margin of the greater trochanter of the femur. The vertical axis (Y axis) was obtained by an imaginary longitudinal line going from the ASIS to the midpoint of the upper margin of the patella. The intersection of the two axis (origin) was considered the center of the coordinate system and was taken as a reference for the location of each arthroscopic portal. The quadrants were named as shown in Figure 2. Finally, a dissection of the inguinal region at the femoral triangle and a dissection of the anterior thigh was performed with emphasis on the preservation of all vascular and nerve structures of the skin, including the lateral femoral cutaneous nerve and its branches, in order to measure their relation to each of the portals of our study (Fig. 3). 
MÉNDEZ-AGUIRRE, O.; MORALES-AVALOS, R.; COMPEÁN-MARTÍNEZ, G. A.; ESPINOSA-URIBE, A. G.; VÍLCHEZ-CAVAZOS, F.; THERIOT-GIRON, M. C.; QUIROGAGARZA, A.; DE LA GARZA-CASTRO, O.; GUZMÁN-AVILÁN, K.; GUZMÁN-LÓPEZ, S. \& ELIZONDO-OMAÑA, R. E. Neurovascular structures at risk during anterolateral and medial arthroscopic approaches of the hip. Int. J. Morphol., 34(2):752-758, 2016.

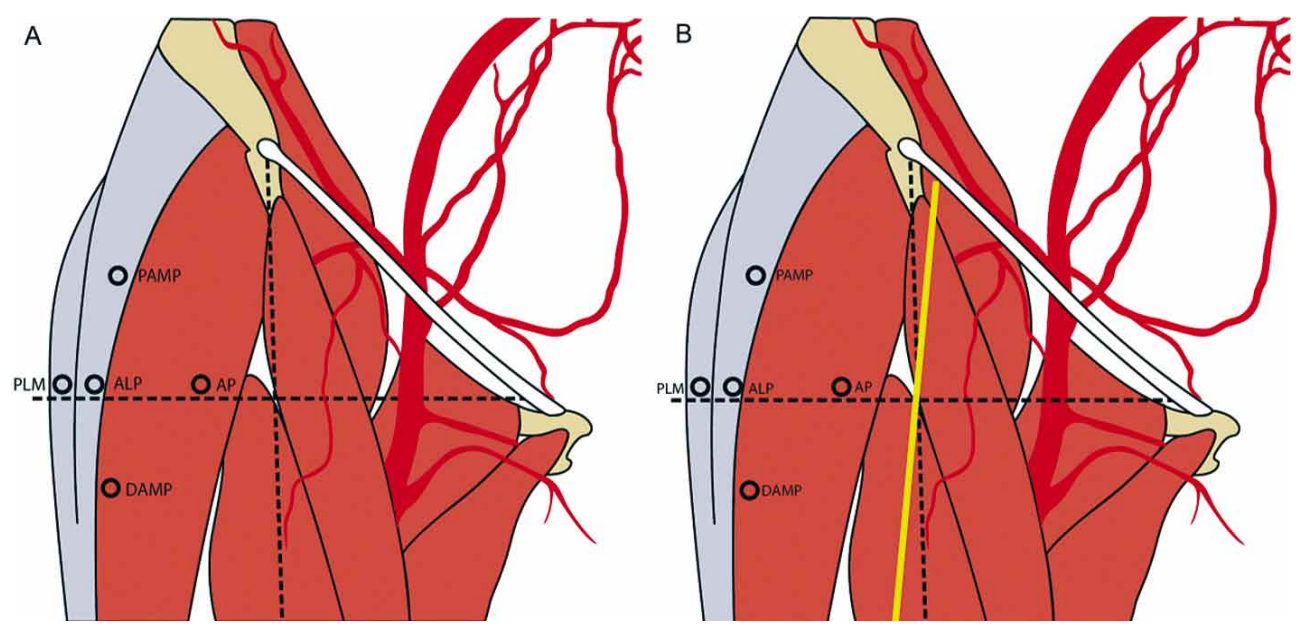

Fig. 2. A) A Cartesian plane is shown, dividing the region into four quadrants for each portal in reference to the $\mathrm{X}$ and $\mathrm{Y}$ axes. $\mathrm{B}$ ) The relationship of the various neurovascular structures is shown relative to the portals. AP anterior portal, ALP anterior lateral portal, PLP posterior lateral portal, PAMP proximal anterior medial portal, DAMP distal anterior medial portal.

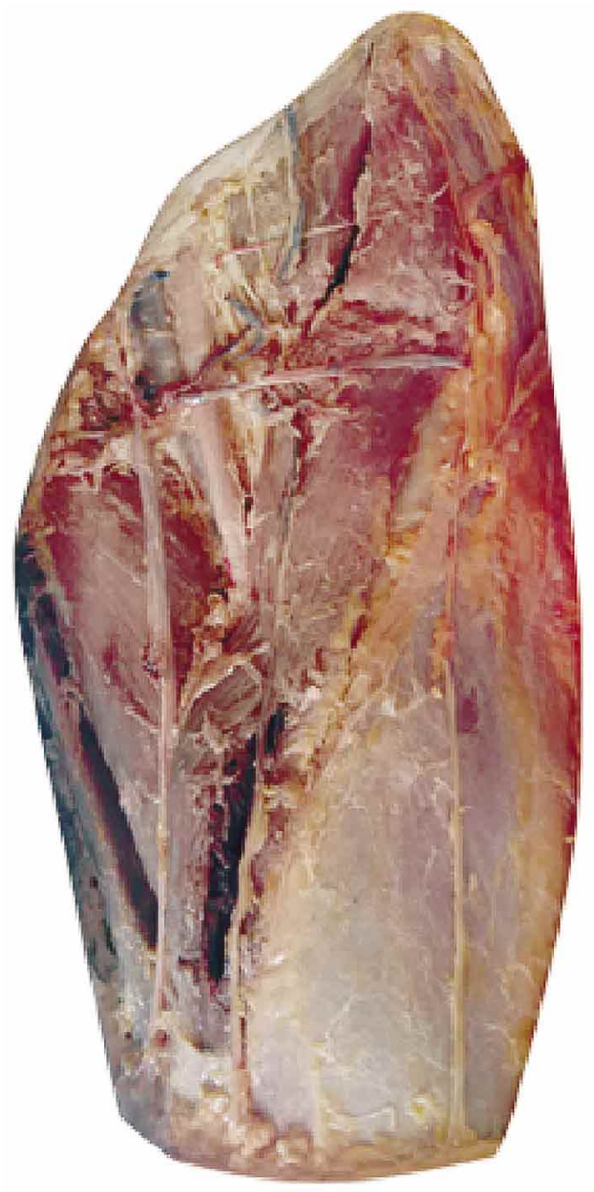

Fig. 3. Photograph of the anatomical dissection of a left hip. The anterior dissection of the femoral triangle and the preservation of the lateral femoral cutaneous nerve (asterisk) is shown.

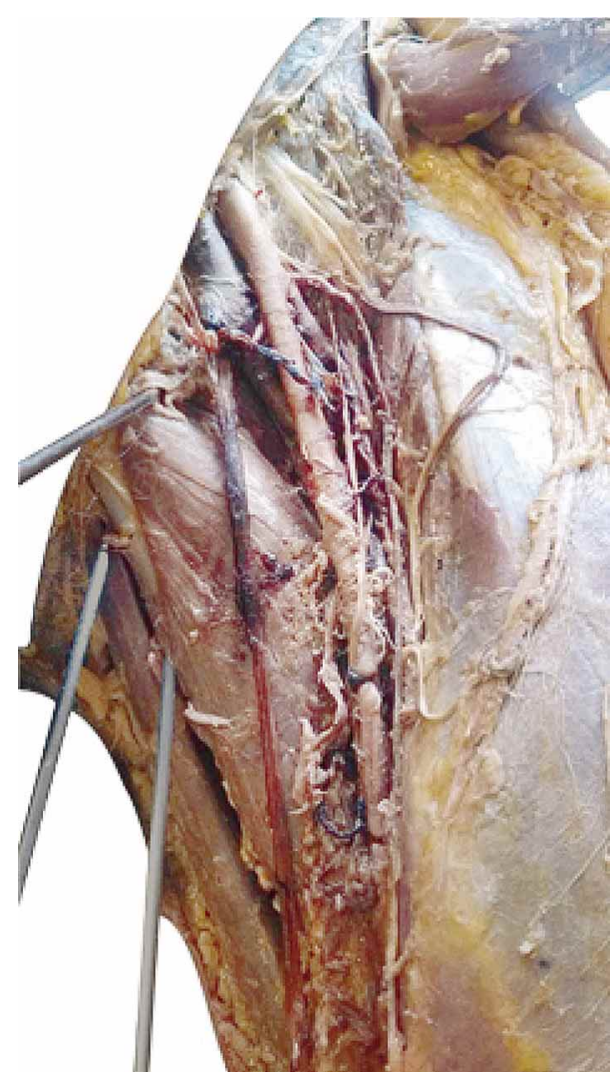

Fig. 4. Photograph of the anatomical dissection of a left hip showing the placement of the three medial portals and their relationship to the femoral bundle. 
MÉNDEZ-AGUIRRE, O; MORALES-AVALOS, R.; COMPEÁN-MARTÍNEZ, G. A.; ESPINOSA-URIBE, A. G.; VÍLCHEZ-CAVAZOS, F; THERIOT-GIRON, M. C.; OUIROGAGARZA, A.; DE LA GARZA-CASTRO, O.; GUZMÁN-AVILÁN, K.; GUZMÁN-LÓPEZ, S. \& ELIZONDO-OMAÑA, R. E. Neurovascular structures at risk during anterolateral and medial arthroscopic approaches of the hip. Int. J. Morphol., 34(2):752-758, 2016.

Anterolateral Portals: The AP is located one centimeter lateral to the origin of the axes; the ALP and PLP were placed on the horizontal axis. The ALP was placed one centimeter anterior and the PLP $1 \mathrm{~cm}$ posterior to the upper margin of the greater trochanter. The PAMP was placed at the midpoint between the AP and the ALP, $5 \mathrm{~cm}$ superiorly. The intersection between these portals allow to imagine a line to form an isosceles triangle in which the PAMP is the vertex with the ALP and AP at the base. The DAMP was also placed between the ALP and AP as was the PAMP, however the location of the DAMP is inverted inferiorly, forming the vertex of the inverted triangle (Robertson \& Kelly).

Medial Portals: The AMP was placed one centimeter from the origin of the adductor longus muscle tendon in the pubic body, located anterior and superior to the muscle. The PMP was also placed $1 \mathrm{~cm}$ from the origin of the adductor longus muscle tendon but located posterior and inferior to the muscle. The DPMP was placed $5 \mathrm{~cm}$ distal to the origin of the adductor longus muscle with a location posterior and inferior to the muscle (Fig. 4).

Once each arthroscopic portal was placed, we proceeded to delimit the safety area of each portal relative to neurovascular structures of clinical importance. Measurements were performed using a digital millimetric vernier with a $0.01 \mathrm{~mm}$ accuracy (Mitutoyo Digimatic / Encoders wSeries 500). A safety area was established when the distance between the portal and a neurovascular structure was greater than $3 \mathrm{~cm}$; when the distance was less than $2 \mathrm{~cm}$ to the portal, it was considered high risk for injury. Those structures between 2 and $3 \mathrm{~cm}$ are considered to be in intermediate risk.

Angular measurements: A $5.5 \mathrm{~cm}$ long cannulated trocar sheath (Linvatec T4930 $4 \mathrm{~mm}$ in diameter), was inserted after placing a guide wire and was then replaced with a 5 $\mathrm{mm}$ in diameter Steinmann nail. Afterwards measuring the angle of insertion of the nail with a conventional goniometer (precision of $0.1^{\circ}$ ) was performed for each portal using a transverse $\mathrm{X}$ axis (anterior to posterior) and a longitudinal $\mathrm{Y}$ axis (superior to inferior). The goniometer was positioned parallel to the skin and the hinge were placed at the point of insertion of the nail.

Statistical analysis: The computer program Microsoft Excel 2013 for Windows XP was used. The mean, standard deviation and range for each parameter of linear and angular measurement was determined. The results are presented in tables.

Ethical considerations: This protocol was approved by the Ethics and Research Committee of the Faculty of Medicine and University Hospital "Dr. José Eleuterio González" U.A.N.L. with the registration number (AH13-003). There were no financial or commercial gains in the completion of this study. The authors declare no conflict of interest.

\section{RESULTS}

A total of twelve hips were analyzed from six male cadavers. The AP has the highest risk due to its proximity to the lateral femoral cutaneous nerve (LFCN) located medial to the portal. The AMP is the medial portal with the highest risk because of its relation with the femoral artery (FA) located lateral to it and the obturator nerve inferior and medial to it.

Anterolateral Portals: The AP were located at an mean distance of $1.47 \pm 5.8 \mathrm{~cm}$ lateral to the origin of axes. The insertion angles used were $30^{\circ}$ posterior on the $\mathrm{X}$ axis and $35^{\circ}$ superior on the $\mathrm{Y}$ axis. The nail punctured the sartorius and rectus femoris muscles as well as the articular capsule in order to enter the hip joint. The structures with a high risk of being injured were the LFCN, located $1.42 \pm 0.85 \mathrm{~cm}$ medial to the portal, the ascending branch of the lateral circumflex femoral artery (LCFA), located $5.44 \pm 1.13 \mathrm{~cm}$ medial to the portal, and the femoral nerve $4.47 \pm 1.03 \mathrm{~cm}$ medial to the portal (Table I).

The ALP was located at a mean distance of $5.93 \pm 0.12$ $\mathrm{cm}$ lateral to the origin of axes and $1 \mathrm{~cm}$ anterior to the upper margin of the greater trochanter. The insertion angles used were $20^{\circ}$ posterior on the $\mathrm{X}$ axis and $15^{\circ}$ superior on the $\mathrm{Y}$ axis. The trocar perforated the tensor fasciae latae (TFL) and the gluteus medius muscle. The nearest structure was the superior gluteal nerve, located at a mean distance of $4.23 \pm 1.33 \mathrm{~cm}$ in a posterior lateral direction. The rest of the means are shown in (Table I).

The PLP was located at a mean distance of $10.69 \pm 0.29 \mathrm{~cm}$ lateral to the origin of axes, $1 \mathrm{~cm}$ posterior to the upper margin of the greater trochanter. The insertion angles were $5^{\circ}$ anterior on the $\mathrm{X}$ axis and $5^{\circ}$ superior on the $\mathrm{Y}$ axis. The trocar perforated through the gluteus medius and gluteus minimus muscles before entering the articular capsule of the hip joint through its posterior area. The most important structure due to its proximity, is the sciatic nerve, at a mean distance of $3.12 \pm 1.33 \mathrm{~cm}$, posterior lateral to the portal (Table I).

The PAMP was located at an intermediate distance between the AP and ALP as mentioned previously. It was located $3.12 \pm 0.79 \mathrm{~cm}$ lateral to the origin of the axes on the 
MÉNDEZ-AGUIRRE, O.; MORALES-AVALOS, R.; COMPEÁN-MARTÍNEZ, G. A.; ESPINOSA-URIBE, A. G.; VÍLCHEZ-CAVAZOS, F.; THERIOT-GIRON, M. C.; QUIROGAGARZA, A.; DE LA GARZA-CASTRO, O.; GUZMÁN-AVILÁN, K.; GUZMÁN-LÓPEZ, S. \& ELIZONDO-OMAÑA, R. E. Neurovascular structures at risk during anterolateral and medial arthroscopic approaches of the hip. Int. J. Morphol., 34(2):752-758, 2016.

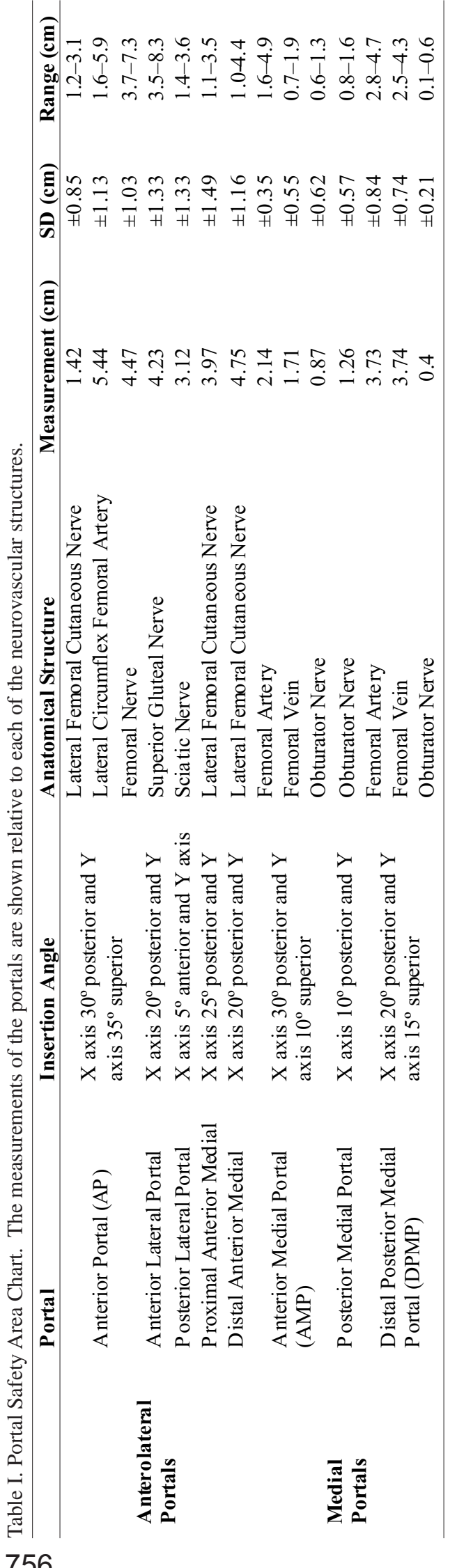

$\mathrm{X}$ axis and $5.07 \pm 0.94 \mathrm{~cm}$ superior on the $\mathrm{Y}$ axis. The insertion angles used were $25^{\circ}$ posterior on the $\mathrm{X}$ axis and $40^{\circ}$ inferior on the $\mathrm{Y}$ axis. It perforated the rectus femoris muscle with the nearest structure being the LFCN at a mean lateral distance of $3.97 \pm 1.49 \mathrm{~cm}$ (Table I).

The DAMP was located in an intermediate distance between the $\mathrm{AP}$ and the ALP, but caudally. It was located $6.03 \pm 2.75 \mathrm{~cm}$ lateral to the origin of the axes on the $\mathrm{X}$ axis and $5.15 \pm 0.78 \mathrm{~cm}$ inferior on the $\mathrm{Y}$ axis. The insertion angles used were $20^{\circ}$ posterior on the $\mathrm{X}$ axis and $15^{\circ}$ on the $\mathrm{Y}$ axis. The nearest structure was the NCFL, located $4.75 \pm 1.16 \mathrm{~cm}$ lateral to the portal (Table I).

Medial portals: The AMP was located on the anterior superior margin of the adductor longus muscle, one centimeter from its insertion on the pubic symphysis. The insertion angles used were $30^{\circ}$ posterior on the $\mathrm{X}$ axis and $10^{\circ}$ superior on the $\mathrm{Y}$ axis. It perforated the pectineus muscle and the articular capsule of the coxofemoral joint. There is risk of injury to the femoral vessels due to its lateral proximity with a mean distance of $2.14 \pm 0.35 \mathrm{~cm}$ for the femoral artery and $1.71 \pm 0.55 \mathrm{~cm}$ for the femoral vein $(\mathrm{FV})$; the obturator nerve $(\mathrm{ON})$ is located $0.87 \pm 0.62 \mathrm{~cm}$ inferior and lateral to the portal (Table I).

The PMP was located in the posterior margin of the adductor longus, one centimeter from its insertion on the pubic symphysis. The insertion angles used were $10^{\circ}$ posterior on the $\mathrm{X}$ axis and $5^{\circ}$ on the $\mathrm{Y}$ axis. It went through the gracilis muscle and passes posterior to the medial margin of the adductor longus before perforating the articular capsule. The nearest structure was the $\mathrm{ON}$, with a mean distance of $1.26 \pm 0.57 \mathrm{~cm}$ medial to the portal (Table I).

The DPMP was located at the posterior inferior margin of the adductor longus muscle, $5 \mathrm{~cm}$ from its insertion on the pubic symphysis. The insertion angles used were $20^{\circ}$ posterior on the $\mathrm{X}$ axis and $15^{\circ}$ superior on the $\mathrm{Y}$ axis. The nearest structure to the portal was the FA with a mean distance of $3.73 \pm 0.84 \mathrm{~cm}$, very similar to $\mathrm{FV}$, with a mean distance of $3.70 \pm 0.74 \mathrm{~cm}$, both located lateral to the portal; the $\mathrm{ON}$ was also at risk, with a distance of $0.40 \pm 0.21 \mathrm{~cm}$ inferior and lateral to the portal (Table I).

\section{DISCUSSION}

In this study we evaluated the safety of 8 hip arthroscopic portals (5 anterior lateral and 3 medial) using a standard surgical technique. A topographic description by quadrants is proposed to describe the safety area of each site and the relationship of the neurovascular structures nearest to each, therefore demonstrating the risk of injury during the portal placement.

The AP has a high risk of injury to the LFCN and the ascending branch of the LCFA. Robertson \& Kelly obtained results similar to ours. The study by Byrd et al. established a smaller distance between these structures and the portal, so care must be taken when placing the trocar. 
MÉNDEZ-AGUIRRE, O; MORALES-AVALOS, R.; COMPEÁN-MARTÍNEZ, G. A.; ESPINOSA-URIBE, A. G.; VÍLCHEZ-CAVAZOS, F; THERIOT-GIRON, M. C.; QUIROGAGARZA, A.; DE LA GARZA-CASTRO, O.; GUZMÁN-AVILÁN, K.; GUZMÁN-LÓPEZ, S. \& ELIZONDO-OMAÑA, R. E. Neurovascular structures at risk during anterolateral and medial arthroscopic approaches of the hip. Int. J. Morphol., 34(2):752-758, 2016.

We suggest that placing the portal lateral to the origin of the axes would increase the safety area in this case. The PLP has a risk of injury to the superior gluteal nerve and the sciatic nerve as is shown in our study, which has similar results to those by Byrd et al.

The anterolateral portals with greater safety areas are: the ALP, located at a safe distance from the superior gluteal nerve, and the PAMP and DAMP whose nearest lateral structure is the LFCN.

As for medial portals, there is limited information describing the safety area and structures at risk of injury. These have only been assessed by Polesello et al., who suggest that the medial approach is safe; however, our results evidence that the safety area is narrow, with high risk of injury, similar to the conclusion made by Koizumi et al. (1996) and Thorey et al. Alwattar \& Bharam (2011) and Bond et al. (2009), consider that the risks outweigh the benefits when using a medial approach. Our study establishes a high risk of injury to the FA. Polesello et al. reported a greater distance, demonstrating a high risk of vascular injury, which may jeopardize not only the circulation of the lower limb, but also the patient's life. As for the nerve structure at risk of injury, the ON is in greater risk when DPMP is used, as was shown by Polesello et al. We consider that the medial approach has an limited safety area in relation to the femoral and obturator nerve bundle. It is important that orthopedic surgeons take these risks into consideration when making decisions during a pre-surgical evaluation.

The anterolateral portals evaluated are safe to use with the LFCN and the ascending branch of the LCFA as the structures at higher risk of injury. The AP has the highest risk. The medial portals have the highest risk of injury to neurovascular structures, the FA, FV and ON being the most at risk. The AMP is the portal with the highest risk.

\section{ACKNOWLEDGEMENTS}

We would like to the thank all the personnel of the Anatomy Department of at the School of Denistry, U.A.N.L. for the support provided for the implementation of this study. We also wish to acknowledge the assistance of Jaime A. Cisneros Rios M.A. in preparing the graphic material presented in this study.

MÉNDEZ-AGUIRRE O.; MORALES-AVALOS, R.; COMPEÁN-MARTÍNEZ, G. A.; ESPINOSA-URIBE, A. G.; VÍLCHEZCAVAZOS, F.; THERIOT-GIRON, M. C.; QUIROGA-GARZA, A.; DE LA GARZA-CASTRO O.; GUZMÁN-AVILÁN, K.; GUZMÁN-LÓPEZ, S. \& ELIZONDO-OMAÑA, R. E. Estructuras neurovasculares en riesgo durante abordajes artroscopicos anterolaterales y mediales de la cadera. Int. J. Morphol., 34(2):752-758, 2016.

RESUMEN: El objetivo fue describir las áreas de seguridad para la colocación de 5 portales estándar (portal anterior, anterolateral, posterolateral, portal anterior proximal medial y portal anterior distal medial) y 3 portales mediales emergentes (antero medial, portal posteromedial y posteromedial distal) para proporcionar una descripción topográfica de la seguridad de cada portal. Se realizó un estudio descriptivo, observacional y transversal, en la que se disecó el triángulo femoral de 12 caderas. Se colocaron los 5 portales laterales y los 3 portales mediales. Se documentó la medición de cada estructura neurovascular de relevancia clínica en relación a cada uno de los portales evaluados. En cuanto al portal de mayor riesgo entre los laterales, se encontró el portal anterior con mayor cercanía al nervio cutáneo femoral lateral $(1,42 \pm 0,85 \mathrm{~cm})$, ubicado lateral al portal. En los portales mediales el portal anterior medial tiene el margen más estrecho respecto a la arteria femoral $(2,14 \pm 0,35 \mathrm{~cm})$ lateral al portal, y medial el nervio obturador $(0,87 \pm 0,62 \mathrm{~cm})$. Los portales laterales tienen un amplio margen de seguridad, el portal con el margen más reducido es el portal anterior en relación al nervio cutáneo femoral lateral, presentando un elevado riesgo de lesionarlo, los portales mediales tienen un alto riesgo de lesionar las estructuras neurovasculares femorales y el nervio obturador.

PALABRAS CLAVE: Anatomía; Artroscopía; Cadera; Portal.

\section{REFERENCES}

Alwattar, B. J. \& Bharam, S. Hip arthroscopy portals. Oper. Techn. Sport Med., 19(2):74-80, 2011.

Bond, J. L.; Knutson, Z. A.; Ebert, A. \& Guanche, C. A. The 23point arthroscopic examination of the hip: basic setup, portal placement, and surgical technique. Arthroscopy, 25(4):416-29, 2009.
Bozic, K. J.; Chan, V.; Valone F. H. 3rd.; Feeley, B. T. \& Vail, T. P. Trends in hip arthroscopy utilization in the United States. $J$. Arthroplasty, 28(8 Suppl.):140-3, 2013.

Byrd, J. W. Hip arthroscopy utilizing the supine position. Arthroscopy, 10(3):275-80, 1994. 
MÉNDEZ-AGUIRRE, O.; MORALES-AVALOS, R.; COMPEÁN-MARTÍNEZ, G. A.; ESPINOSA-URIBE, A. G.; VÍLCHEZ-CAVAZOS, F.; THERIOT-GIRON, M. C.; QUIROGAGARZA, A.; DE LA GARZA-CASTRO, O.; GUZMÁN-AVILÁN, K.; GUZMÁN-LÓPEZ, S. \& ELIZONDO-OMAÑA, R. E. Neurovascular structures at risk during anterolateral and medial arthroscopic approaches of the hip. Int. J. Morphol., 34(2):752-758, 2016.

Byrd, J. W.; Pappas, J. N. \& Pedley, M. J. Hip arthroscopy: an anatomic study of portal placement and relationship to the extra-articular structures. Arthroscopy, 11(4):418-23, 1995.

Gupta, A.; Redmond, J. M.; Hammarstedt, J. E.; Schwindel, L. \& Domb, B. G. Safety measures in hip arthroscopy and their efficacy in minimizing complications: a systematic review of the evidence. Arthroscopy, 30(10):1342-8, 2014.

Koizumi, W.; Moriya, H.; Tsuchiya, K.; Takeuchi, T.; Kamegaya, M. \& Akita, T. Ludloff's medial approach for open reduction of congenital dislocation of the hip. A 20-year follow-up. $J$. Bone Joint Surg. Br., 78(6):924-9, 1996.

Matsuda, D. K. Acute iatrogenic dislocation following hip impingement arthroscopic surgery. Arthroscopy, 25(4):400-4, 2009.

Nossa, J. M.; Fuerte Díaz, M.; Rueda Escallón, G. \& Pesántez, R. Artroscopia de cadera: indicaciones y resultados. Rev. Colomb. Ortop. Traumatol., 21(4):246-56, 2007.

Philippon, M. J. New frontiers in hip arthroscopy: the role of arthroscopic hip labral repair and capsulorrhaphy in the treatment of hip disorders. Instr. Course Lect., 55:309-16, 2006.

Philippon, M. J.; Stubbs, A. J.; Schenker, M. L.; Maxwell, R. B.; Ganz, R. \& Leunig, M. Arthroscopic management of femoroacetabular impingement: osteoplasty technique and literature review. Am. J. Sports Med., 35(9):1571-80, 2007.

Polesello, G. C.; Omine Fernandes, A. E.; de Oliveira, L. P.; Tavares Linhares, J. P. \& Queiroz, M. C. Medial hip arthroscopy portals: an anatomic study. Arthroscopy, 30(1):55-9, 2014.

Robertson, W. J. \& Kelly, B. T. The safe zone for hip arthroscopy: a cadaveric assessment of central, peripheral, and lateral compartment portal placement. Arthroscopy, 24(9):1019-26, 2008.

Sampson, T. G. Complications of hip arthroscopy. Clin. Sports Med., 20(4):831-5, 2001.

Thorey, F.; Ezechieli, M.; Ettinger, M.; Albrecht, U. V \& Budde, S. Access to the hip joint from standard arthroscopic portals: a cadaveric study. Arthroscopy, 29(8):1297-307, 2013.
Correspondence to:

Rodolfo Morales Avalos M.D

Department of Human Anatomy

Faculty of Medicine

Universidad Autónoma de Nuevo León (U.A.N.L.)

Ave. Madero s/n Col. Mitras Centro

Monterrey, Nuevo León

MÉXICO

Email: rodolfot59@hotmail.com

Received: 20-10-2015

Accepted: 29-02-2016 